\title{
GLL
}

$00=0$ Geomatics, Landmanagement and Landscape No. $2 \cdot 2019,21-36$

\section{ENVIRONMENTAL IMPACT ASSESSMENT OF A PLANNED CONSTRUCTION PROJECT - CASE STUDY OF THE TUCHÓW BYPASS}

\author{
Grażyna Gawrońska, Krzysztof Gawroński, Karol Król, Hubert Buzowski
}

\begin{abstract}
Summary
The objective of the present work is to analyse the environmental impact assessment of the project consisting in the construction of the Tuchów bypass (Tarnów district of the Małopolska Region, Poland) as well as to verify the correctness of the report on the impact of the said project on the environment. The paper presents issues related to environmental impact assessment and a detailed analysis of the impact of the planned project on particular elements of the natural environment, including soil and water conditions, land surface, surface and underground water, atmospheric air, acoustic climate, as well as waste management. The conclusions are based on the results of the research and descriptive analysis. It has been demonstrated that the report on the impact of the Tuchów bypass road construction project on the environment has been prepared correctly, and the investment project in question will not have a negative impact on the environment or human health.
\end{abstract}

\section{Keywords}

impact assessment analysis $\bullet$ road infrastructure $\bullet$ investment in linear infrastructure $\bullet$ environmental protection

\section{Introduction}

The term "environmental impact assessment" (abbreviated as EIA) is specified in the Act on access to information on the environment and its protection, public participation in environmental protection, and environmental impact assessments [Act 2008]. Assessment of the project's environmental impact is an administrative procedure regarding the given planned venture, which in particular includes: (1) the analysis and verification of the environmental impact report, (2) obtaining the approvals and opinions required by law, and (3) providing the public with opportunities to participate in the said proceedings. Carrying out the environmental impact assessment is required of all planned projects that may significantly affect the environment, and that are listed in the regulation of the Council of Ministers of 9 November 2010 on projects that may significantly affect the environment [Regulation 2010b]. These cover two groups of projects: 
(1) planned projects that can always have a significant impact on the environment, and

(2) planned projects that could potentially significantly affect the environment (whereas the obligation to conduct the assessment is determined by the competent authority) [Act 2008]. The environmental impact assessment is the first stage in the project planning process, and a key tool in the environmental protection process, seeing that the values and assets of the environment can be jeopardized by the implementation of the planned investment. The purpose of the EIA is to ensure that important and valuable environmental values are recognized already at the planning stage of a given investment project, and protected thanks to the creation of spatial plans and issuing appropriate planning decisions [Bugajska and Kulig 2014]. The environmental impact assessment makes it possible to present the effects and threats related to the implementation of an investment project to all entities involved in the planning of that project [Dubel 2005].

\section{Purpose and goals of the research}

Road construction projects, with particular emphasis on city bypasses, bring a number of benefits. They contribute to reducing emissions of transport-related pollution to the natural environment, and improve the acoustic climate in built-up areas. Construction investment projects of this type improve communication in the region, inter alia by linking regional infrastructure with external systems and shortening travel time, and increasing the level of safety of road users. They also have a positive effect on developing the potential of the region as a whole. At the same time, road investments may also have a negative impact on the environment. The aim of the present work is to analyse the environmental impact assessment of the investment project consisting in the construction of the Tuchów bypass, as well as the verification of the report on the impact of this project on the environment.

The construction of the bypass was included in the Local Spatial Development Plan of the Town and Municipality of Tuchów [Resolution 2008] and in the Spatial Development Plan of the Małopolska Region [Resolution 2003]. Based on the regulation by the Council of Ministers of 9 November 2010 on projects that may have a significant impact on the environment, the project has been qualified as potentially having a significant impact on the environment. The competent authority to proceed with the decision on environmental conditions was the Regional Director for Environmental Protection in Kraków, as the construction project was planned in a restricted area. The obligation to carry out an environmental impact assessment was imposed by the Regional State Sanitary Inspectorate in Tarnów.

\section{Environmental Impact Assessment}

The primary documents defining the principles of conducting environmental impact assessments in Poland include the Act on access to information on the environment and its protection, public participation in environmental protection and environmental impact assessments of 2008 [Act 2008] and the Regulation by the Council of Ministers 
of November 9, 2010 on projects that may significantly affect the environment (hereinafter: RRM) [Regulation 2010b]. The Act sets out the rules and the procedure for the conduct of environmental impact assessments, and for providing information on the environment and its protection, public participation in environmental protection, as well as listing the administrative bodies and public authorities that are appropriate for issuing decisions, approvals, and opinions. The regulation specifies for which projects it is necessary to carry out an environmental impact assessment thereof. The Act is based on European Union legislation, in particular: (1) Directive 2011/92/EU of the European Parliament and of the Council of 13 December 2011 on the assessment of the effects of certain public and private projects on the environment (Environmental Impact Assessment - EIA Directive) [Directive 2011] and (2) Directive 2001/42/EC of the European Parliament and of the Council of 27 June 2001 on the assessment of the effects of certain plans and programs on the environment (Strategic Environmental Assessment - SEA Directive) [Directive 2001].

Planned projects for which the environmental impact assessment is carried out, were divided into three groups [Act 2008]:

- Group I - planned projects that can always significantly affect the environment (listed in the RRM),

- Group II - planned projects that may potentially significantly affect the environment (listed in the RRM),

- Group III - projects other than those specified in the first and second group require an assessment of the impact of the project on the Natura 2000 areas if the project may significantly affect this area, is not directly related to its protection or does not result from this protection, or an obligation the assessment of the project's impact on the Natura 2000 site has been confirmed. These are projects not listed in the RRM [Act 2008].

The RRM Regulation lists the types of projects that can always have a significant impact on the environment, for which an environmental impact assessment is obligatory, as well as types of projects that may potentially have a significant impact on the environment, for which the environmental impact assessment is optional.

In the national EIA system, as in the European system, there is the National Commission for Environmental Impact Assessments (KKOOŚ). It is an advisory and consultative body of the General Directorate for Environmental Protection (GDOŚ). The KKOOŚ consists of persons recruited from academic communities, research institutes in the field of environmental protection and experts from state offices, as well as from environmental (ecological) organizations. The scope of operation and tasks of the KKOOŚ have been specified in the UOOŚ Act.

\section{Environmental impact assessment in Europe}

In European Union law, the environmental impact assessment is a procedure that takes into account the impact of investment projects on environmental assets before a deci- 
sion is issued. The assessment of environmental impact is carried out on the basis of the Directive of the European Parliament and of the Council 2011/92/EU (Environmental Impact Assessment - EIA Directive). This directive applies in the case of performing EIAs for investment projects such as the construction of a motorway, an airport, or a factory. For public plans and programs, the provisions of Directive 2001/42/EC of the European Parliament and of the Council (Strategic Environmental Assessment - SEA Directive) apply. Both of these directives ensure the implementation of an EIA for any investment project that can have a significant impact on the environment. Conducting an environmental impact assessment in accordance with the directives is necessary in order to apply for co-financing from the European Union budget for the implementation of a given project.

Directive 2011/92/EU of the European Parliament and of the Council [Directive 2011] defines the principles for assessing the environmental impact of public and private projects that may have significant effects on the environment. The second article of the said directive obliges European Union Member States to carry out an environmental impact assessment for investment projects, which due to their nature, size and location, may have a negative impact on the environment. The EIA should be carried out before issuing the permit for the investment project. Furthermore, the EIA Directive specifies for which elements the direct and indirect impact of the project needs to be determined.

Directive 2001/42/EC of the European Parliament and of the Council [Directive 2001] guarantees a high level of environmental protection and an assessment of the environmental impact of plans and programs that can significantly affect the environment. According to the provision contained in the fourth article of the above directive, the environmental impact assessment should be made during the preparation of the plan or program and before its adoption [Directive 2001]. The EIA/SEA national expert committee consists of environmental experts nominated from EU member states. Committee meetings are held twice a year and its task is to provide the European Commission with expert opinions and advice on the implementation of the new EIA and SEA directives.

\section{Environmental impact assessment report}

The environmental impact assessment report is one of the key elements of the environmental impact assessment procedure. For projects that can always have a significant impact on the environment, the environmental impact assessment report should be attached to the application for a decision on environmental conditions or provided after determining its scope by the authority issuing the decision. For projects that could potentially have a significant impact on the environment, the report is prepared when the applicant is required to carry out an environmental impact assessment [Gawrońska and Policht-Latawiec 2014].

According to article 66, passage 1 of the UOOS (UAE), the report on the impact of the given investment project on the environment should contain information that will 
enable the analysis of the impact of that project on people and on specific elements of the environment.

\section{Decision on environmental conditions}

The initiation of procedure regarding the issue of a decision on environmental conditions (DŚU) takes place at the moment the investor submits the application for the issuance of that decision. The exception is the situation of land consolidation or exchange, where the procedure is initiated automatically (that is, ex officio) [Florkiewicz and Kawicki 2009].

The authority competent to issue a decision on environmental conditions, for most of the undertakings listed in the ordinance of the Council of Ministers of 9 November 2010 [Regulation 2010b], is the head of the municipality or a city mayor.

The decision on environmental conditions determines the environmental conditions for the implementation of the given project, that is to say, the environmental protection requirements that must be met at each stage of the implementation of that project, during the operation or use of the given infrastructure, as well as its liquidation. Obtaining a decision on environmental conditions is required for projects that can always and potentially significantly affect the environment, and it is necessary in order to obtain a permit for the implementation of a given project.

\section{Material and methods}

It was assumed that the specified research objective would be implemented by means of the analysis of existing data. This method is often used due to the relatively easy access to primary data, which can provide high quality source material [Król et al. 2017]. The source material in this case was the report on the environmental impact of the project consisting in the construction of the Tuchów bypass, entitled: Budowa wschodniego obejścia Tuchowa w ciagu drogi wojewódzkiej nr 977 (Construction of the eastern bypass road of Tuchów city along the provincial road No. 977) [Report 2011]. The report was made at the request of the investor, that is the Zarząd Dróg Wojewódzkich Regional Roads Authority in Krakow. The text of the report was obtained from the Regional Directorate for Environmental Protection in Kraków (Department of Land Affairs in Tarnów). The conclusions are based on the results of the descriptive analysis. The influence of Tuchów bypass on particular environmental elements was analysed in detail, including: soil and water conditions, ground surface, surface water and underground water, atmospheric air, acoustic climate, as well as waste management.

\section{Description of the studied area}

Tuchów is located in the south of Poland, in the Małopolska Region, in the Tarnów district, or district (Fig. 1). The distance from Tuchów to the poviat town (district capital) of Tarnów, in the straight line, is approximately $14 \mathrm{~km}$, and to Kraków, which is the capital of the Małopolska Region, it is about $82 \mathrm{~km}$. 


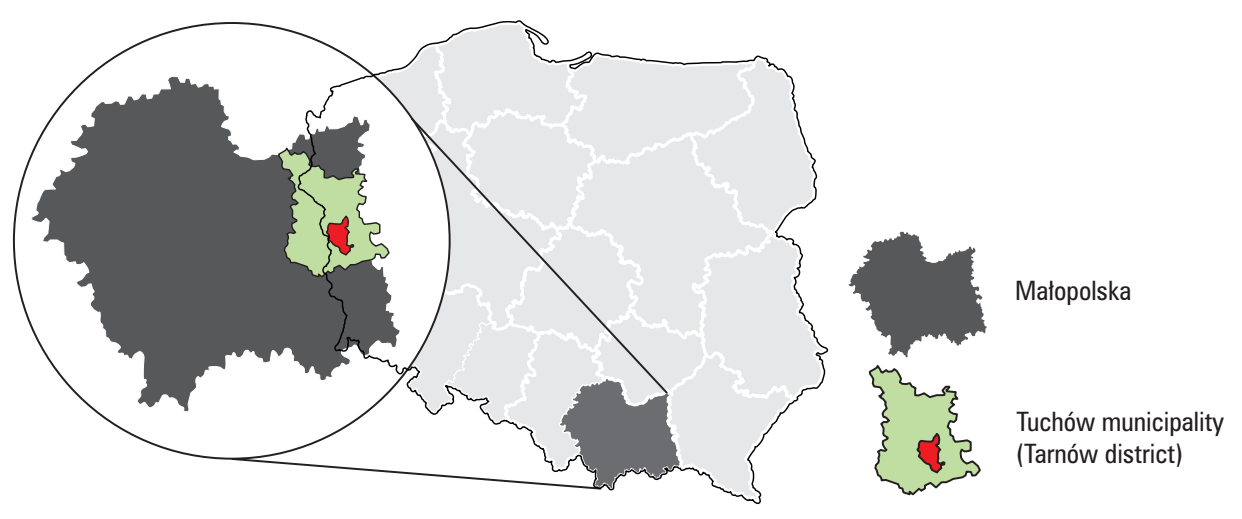

Source: authors' own elaboration

Fig. 1. Location of Tuchów municipality in the Tarnów district and the Małopolska Region

The city of Tuchów is located in a hilly area. From the south-east it is surrounded by the Liwocza and Brzanka mountain range, whose highest elevations are Liwocz (562 $\mathrm{m}$ above sea level) and Brzanka (536 m above sea level). From the west, the hills of the Meszniańsko-Ryglicki Garbów adjoin the town, with the so-called shoulder of the Słona Mountain (403 m above sea level) to the north and north-west. The areas of the plateau are covered with thick forests. Furthermore, due to the location in the valley, there is a high risk of flooding in the event of increased rainfall [Kozioł 2008]. This area is dominated by brown soils formed from clasts, turning into clayey soils on the slopes. In the Brzanka range, brown skeletal soils often occur. The valley of the Biała River is covered by medium and heavy fluvisols, whereas flat areas are covered by deluvial brown soils. The soils in this area mostly belong to the IIIa class, which possesses high agricultural suitability. Hence, in the structure of land use, agricultural land constitutes the majority (over 50\%), whereas the municipality itself is agricultural in character. Agricultural holdings of a small size prevail, which is typical in the area of southern Poland.

\section{Description of the planned project}

The planned project encompasses the construction of the Tuchów bypass within the regional road No. 977 of class G1/2. The scope of work envisages the construction of a new bridge facility on the Biała River and viaducts over the streets of Polna and Kolejowa. In addition, a viaduct over the railway tracks is planned. Furthermore, the construction of water culverts is planned in places where the road will have a flood function. Most of the bypass will be routed in an embankment that will function as a flood protection structure on the section from the bridge over the Biała River to Ryglicka Street. The investment project provides for the construction and reconstruction of the existing utilities network, performing the excavations, building the embank- 
ments, and possible replacement and supplementation of the substrate, introducing the markings and elements to increase traffic safety, the felling of trees where necessary, and fitting the infrastructure necessary to protect the environment. After the completion of the investment project, roadside areas will be reclaimed, and the accessibility will be improved by the construction of side roads.

\section{Analysis of the assessment of the given project's impact on the natural environment}

The analysis of the assessment of impact that the construction of the Tuchów bypass will have on specific elements of the environment was made on the basis of the report on the impact of the project on the environment, titled Budowa wschodniego obejścia Tuchowa w ciagu drogi wojewódzkiej nr 977 (Construction of the eastern bypass road of Tuchów city along the provincial road No. 977) [Report 2011].

Soil and water conditions, and land surface

A characteristic consequence of construction works is the degradation of the topsoil layers, which is mostly temporary, as it is relatively easy to restore them to their original state, that is, one from before the works had started. Works related to the construction of the bypass require repeated exposure of the soil, resulting in the degradation of humus. In order to limit the negative impact of the implementation of the construction project on the soil layer, it is necessary - after the completion of construction or disassembly works - to restore its condition that does not threaten the soil quality balance of the area. In order for the investment project to have the least impact on the subsoil during implementation, it is foreseen that the existing soil dumps should be used, so as not to create additional special waste. Due to the form of the terrain, flood risk and the existing obstacles, most of the bypass will be routed within the embankment. The road will be located on appropriately reinforced and levelled ground, and a suitably selected number of insulating layers will not allow the contamination created during its use to reach the unprotected areas. Soil and water conditions are satisfactory in the analysed area, with adequate permeability and thickness.

\section{Surface water}

The condition of surface waters in the area of the planned investment project is stable, and the waters are characterized by a low degree of pollution. Correct implementation of the investment project will not disturb local water regime, and the water and sewage management will be solely based on discharging thaw and rainwater from the construction areas.

Rainwater will be discharged from the bypass road through curbs installed in the crossing areas with gullets for rainwater drainage and surface runoff to roadside ditches. The main receiving water body for rainwater is the Biała River. Due to the 
lack of exceedances of the permissible concentrations of total suspended solids, it is planned that separators and settling tanks will be installed only at the outlets from the rainwater drainage system from the bridge over the Biała River. Other outlets will not be equipped with pre-treatment devices.

The method for solving the problem of rainwater management, which is presented in the report should ensure the discharge of pollutant load in line with the values contained in the regulation by the Minister of the Environment of 24 July 2006 on the conditions to be met when introducing sewage into waters or to the soil, and on substances particularly harmful to the aquatic environment [Regulation 2006]. The Regulation (Article 19) requires the investor to purify rainwater before it is discharged into surface waters or into the ground if the limit values of $100 \mathrm{mg} / \mathrm{l}$ for general suspended solids and $15 \mathrm{mg} / \mathrm{l}$ for oil-derived hydrocarbons have been exceeded. For the analysed investment project, the concentrations of substances calculated for 2015 and 2025 have not been exceeded, which does not necessitate the necessity of pretreatment before they are discharged to the Biała River.

No negative impact of the Tuchów bypass on the condition of surface waters is expected, and the deterioration of their condition may occur only in the event of a failure, for instance, an explosion during a traffic accident or a chemical leak. At the stage of construction and operation, no intentional use of any substances that could have a negative impact on the quality of surface water in a given area is foreseen, which, however, does not exempt the investor from the obligation to monitor the course of construction works.

\section{Underground water}

Within the Tuchów municipality there is the Main Underground Water Reservoir No. 434 - in the valley of Biała Tarnowska river. Its area amounts to $3.9 \mathrm{~km}^{2}$. The Tuchów bypass will run along its western part. The level of groundwater contamination and the penetration of contaminants located on the surface of the soil deep into the earth are closely related to the concentration of activities in the area as well as to hydrogeological conditions. In order to determine the threat to the implementation of the investment project on groundwater in the analysed area, potential threats that result from the geological structure of the reservoir and land development can be specified, as well as current hazards resulting from pre-existing pollution sources.

The impact of the planned investment on groundwater will depend on the number of vehicles using the bypass road and on how the pollutants flowing from the roadway will be limited. Average traffic volume of vehicles using the infrastructure causes a potential threat of contamination to the area and penetration of petroleum substances, gas and fumes, along with rainwater, to groundwater. In order to limit the impact on the groundwater reservoir, a sealed drainage system was designed to drain rainwater from the roadway, whereas on the sections without drainage, rainwater will be discharged through roadside ditches. Due to the use of such a stormwater drainage system, the expected amount of contaminants entering groundwater will be negligible. 


\section{Atmospheric air}

The influence of the construction of the Tuchów bypass on the quality of atmospheric air was examined on two sections of the road with constant traffic, considered as linear sources of pollutant emissions resulting from the combustion of fuel in the engines of vehicles using the bypass road. Studies have shown that for all substances, with the exception of nitrogen oxides, $10 \%$ of the reference value will not be exceeded for one hour, which means that it is not necessary to carry out full diffusion calculations for those substances. Furthermore, there are no exceedances of the permissible average annual values, which have been established for the protection of human health - with the exception of PM10 particulate matter, for which a disposable value of 0 has been set - due to the exceeded background. The highest concentration values calculated for particulate matter PM10 do not exceed $10 \%$ of the reference value D1, therefore it is not necessary to perform spread calculations. In the case of nitrogen oxides, there are no specific limit values per 1 hour, however, assuming that $100 \%$ of nitrogen oxides are converted to nitrogen dioxide, the limit values of $200 \mu / \mathrm{m}^{3}$ will not be exceeded.

\section{Acoustic climate}

The permissible noise level results from the Regulation by the Minister of the Environment of 14 June 2007 on permissible noise levels in the environment [Regulation 2007]. According to the provisions of Resolution No. XVI I/144/2008 of the Municipal Council in Tuchów of 27 February 2008 regarding the adoption of the local spatial development plan of the Municipality of Tuchów [Resolution], the areas within the potential acoustic impact of the planned investment include:

- Areas of farm buildings within farming, livestock and horticultural holdings, for which, according to the Regulation by the Minister of the Environment of 14 June 2007 [Regulation 2007], the limit values were adopted at $60 \mathrm{~dB}$ during the day time (6:00-22:00) and $50 \mathrm{~dB}$ at night (22:00-6:00),

- Built-up areas with single-family housing (MN), for which, in accordance with the Regulation [2007], the limit values were set at $55 \mathrm{~dB}$ during the daytime period (6:00-22:00) and $50 \mathrm{~dB}$ at night (22:00-6:00).

The range of impact of the planned investment project on the acoustic climate was determined on the basis of calculations made in accordance with Directive 2002/49/EC of the European Parliament and of the European Council of 25 June 2002 on the assessment and control of noise in the environment [Directive 2002]. The modelling was performed using the method "NMPBLRoutes L96 (SETRALCERTUL LCPCLCSTB)". The calculations were made using the Sound Plan 7.1 software. The sound power was determined based on the document library attached to the Sound Plan 7.0 software. The modelling has shown that the isolation of normative noise level runs through a residential building located at Polna street. Therefore, the installation of sounds screens with a height of 4 meters is planned in this location. 
The construction of the Tuchów bypass road will significantly improve the acoustic climate in the city, due to the reduction in the number of vehicles passing through the city centre, and the resulting reduction in noise levels by approximately $4-5 \mathrm{~dB}$.

\section{Waste management}

The implementation of the investment project will generate a large amount of waste of various origins and a substantial assortment. Construction waste generated during construction and decommissioning should be reduced to a minimum, and exported from the construction site on an on-going basis. Responsibility for waste generated during the construction of the bypass road will rest with the contractor.

As a result of works related to the preparation of the area for the investment, heaps of humus and soil from unpaved areas will be created. In order for the humus layer not to be classified as special waste, it is necessary to specify the ways of its management in the construction permit. The waste was estimated at about 7500 $\mathrm{m}^{3}$ for humus and $25000 \mathrm{~m}^{3}$ for soil heaps. In addition, other waste is expected, the amount of which is difficult to estimate. This is associated with the demolition of the existing technical infrastructure installations, and the construction of roads and utilities. These are the following types of waste: concrete, brick rubble, ceramic materials and items of equipment containing dangerous substances, steel and iron, mineral hydraulic oils, plastics, mineral engine oils, gear and lubricating oils, plastic packaging, packaging containing residues of hazardous substances or contaminated packaging, sorbets, filter materials, wiping cloths and protective clothing contaminated with dangerous substances.

The soil heaps that will be created during the construction works will be fully managed and utilised within the area of the investment as a material for levelling the area. In the case of excess material, the soil waste will be transported to the place indicated by the investor.

The humus layers will be reused for biological regeneration of the construction area, and any excess will be used for biological regeneration of areas that are not related to the project in question. Other waste in the form of debris created during the demolition of the installation and construction waste will be stored in municipal landfills. All waste will be sorted and regularly exported from the construction area by companies that specialize in waste management. A hazardous waste landfill shall be appropriately marked, and the waste shall be stored in a manner that does not endanger the environment or human health and life.

After completing the construction works, the investor will become the manager of the road, and will be responsible for selecting - in a tender procedure - the entities providing services in the field of maintenance of storm water drainage, street lighting, greenery and cleaning in road lanes. These services should be provided throughout the city, and not limited to the area of the construction project. Due to the nature of the investment project, the waste generated during its operation is mainly municipal waste and non-hazardous waste. Until the collection of waste by authorized companies, it 
will be stored in compliance with the retention periods specified in the Act on Waste Management [Act 2001]. From the point of view of waste management, there are no obstacles to establishing environmental conditions for the investment project in the indicated location.

\section{Verification of the environmental impact report of the Tuchów bypass road}

The impact of the project on the climate will be local, and its possible changes will result from the heating of the road surface and nearby biologically active areas, which will not significantly affect the environment. Air quality will deteriorate due to the direct nature of emissions. The impact of the investments project on the acoustic climate will be related to the noise and vibrations generated. During the construction works, these changes will be temporary, however in the operation phase this impact will be direct and permanent (Table 1).

Table 1. Types of significant impact of Tuchów bypass on particular elements of the environment

\begin{tabular}{|c|c|c|c|c|c|c|c|c|c|c|}
\hline \multirow[b]{2}{*}{$\begin{array}{l}\text { Elements of the } \\
\text { environment }\end{array}$} & \multirow[b]{2}{*}{ Manner of impact } & \multicolumn{9}{|c|}{ Type of impact } \\
\hline & & 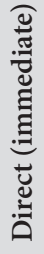 & 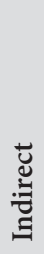 & 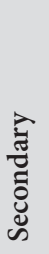 & 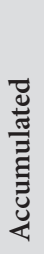 & 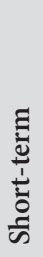 & 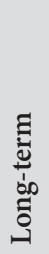 & 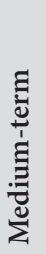 & 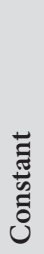 & 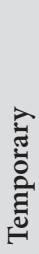 \\
\hline \multirow{2}{*}{ Acoustic climate } & Noise & + & - & - & - & + & - & + & + & + \\
\hline & Vibrations & - & + & - & - & + & - & + & + & + \\
\hline Atmospheric air & Emission of pollutants & + & - & - & - & + & - & + & + & + \\
\hline \multirow{3}{*}{$\begin{array}{l}\text { Surface and } \\
\text { underground water }\end{array}$} & Use of water resources & + & - & - & - & + & - & - & - & + \\
\hline & Change of the water regime & - & - & - & - & - & - & - & - & - \\
\hline & $\begin{array}{l}\text { Emission of pollutants to } \\
\text { the water }\end{array}$ & + & - & - & - & + & - & + & + & + \\
\hline Climate & Change of microclimate & - & - & - & - & - & - & - & - & - \\
\hline Geology & Use of mineral resources & - & - & - & - & - & - & - & - & - \\
\hline \multirow{2}{*}{ Soil } & Occupancy of the area & + & - & - & - & + & + & + & + & + \\
\hline & $\begin{array}{l}\text { Changes of soil features } \\
\text { and quality }\end{array}$ & + & - & - & - & + & - & - & - & + \\
\hline Fauna and flora & Disrupting continuity & + & - & - & - & - & - & - & + & - \\
\hline
\end{tabular}


Table 1. cont.

\begin{tabular}{|c|c|c|c|c|c|c|c|c|c|c|}
\hline \multirow[b]{2}{*}{$\begin{array}{l}\text { Elements of the } \\
\text { environment }\end{array}$} & \multirow[b]{2}{*}{ Manner of impact } & \multicolumn{9}{|c|}{ Type of impact } \\
\hline & & 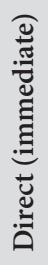 & $\begin{array}{l}\overleftarrow{\mathscr{J}} \\
\stackrel{\Xi}{\Xi} \\
\Xi\end{array}$ & 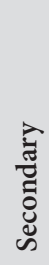 & 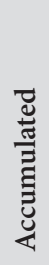 & & 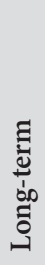 & 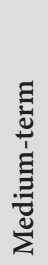 & 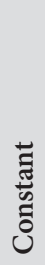 & 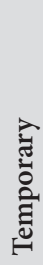 \\
\hline \multirow{2}{*}{ Cultural heritage } & $\begin{array}{l}\text { Destruction of fragments } \\
\text { of heritage objects }\end{array}$ & - & - & - & - & - & - & - & - & - \\
\hline & $\begin{array}{l}\text { Deposition of dust } \\
\text { (particulate matter) }\end{array}$ & - & - & - & - & - & - & - & - & - \\
\hline Landscape & Changes in the landscape & + & - & - & - & - & - & + & + & - \\
\hline Waste & Production of waste & + & - & - & - & + & - & - & - & + \\
\hline $\begin{array}{l}\text { Anthropogenisation } \\
\text { of the area }\end{array}$ & $\begin{array}{l}\text { Development of } \\
\text { infrastructure and services }\end{array}$ & - & - & - & - & - & - & - & - & - \\
\hline \multirow{3}{*}{ Population } & Impact on human health & + & - & - & - & + & - & + & + & + \\
\hline & Road traffic safety & + & - & - & - & + & - & + & + & + \\
\hline & Change of land use & - & - & - & - & - & - & - & - & - \\
\hline
\end{tabular}

Key: +/- significant impact occurs / does not occur

Source: elaborated by the authors based on [Report 2011]

Significant impact of the investment project on surface water and groundwater will be related to the emission of pollutants into the water, and the use of water resources. Emission of pollutants will occur both in the construction phase and during the operation of the bypass road. The calculations that had been conducted demonstrated that harmful substances and other pollutants discharged by the sewage system should not exceed the admissible values. These calculations constitute the basis for asserting that the proposed solutions aimed at limiting the negative impact on the environment on the part of substances flowing with meltwater and rainwater from the bypass road area will not cause a threat to the environment. Environmental impact related to the use of water resources will be immediate and temporary.

In the construction phase, the investment project will have a constant impact on the environment due to the use of biologically active surface. The use of soils in the vicinity of the main road and access roads, as well as for planting the greenery, will be of a temporary character. If the land is occupied by machinery, this type of impact will be of short-term nature. Impacts related to the use of mineral resources such as stone, sand or gravel, which will be used in the construction of the bypass road, as well as the change of the terrain through excavations and embankments, will be direct and permanent. 
The construction of the bypass road may cause fragmentation of ecosystems, due to disrupting the continuity of the Biała River ecological corridor by the construction project. The discussed project will also have a significant impact on the landscape and scenic values. This impact is direct and permanent.

In the case of cultural heritage, the planned investment does not have a significant impact on nearby cultural assets.

In the implementation and operation phase of the project, waste will be generated. This will have a significant impact on the environment at the stage of construction of the bypass road, whereas it will have a direct and temporary character.

The construction stage of the planned investment project will be connected with a short-term impact related to road and construction noise as well as emissions of pollutants into the air. During the operational phase of the bypass road, air pollution, noise and vibrations will be created, which will adversely affect people and the environment - having said that, the density of buildings in the immediate vicinity of the investment is low. This impact will be direct and permanent.

In order to verify the correctness of the report on the impact of the project on the environment, a list of 21 questions was developed, based on which the correctness of the report elaboration was asserted. Questions were formulated on the basis of article 66 of the UOOŚ [Act 2008].

Table 2. Verification of the correctness of the report on the impact of the planned investment project on the environment

\begin{tabular}{|c|c|c|}
\hline No. & Question & $\begin{array}{l}\text { Answer } \\
\text { YES /NO }\end{array}$ \\
\hline 1 & $\begin{array}{l}\text { Does the report contain a description of the planned project along with its } \\
\text { characteristics and conditions of land use during the construction and operation } \\
\text { phase? }\end{array}$ & YES \\
\hline 2 & $\begin{array}{l}\text { Does the report contain a description of the elements of the natural environment } \\
\text { covered by the expected environmental impact of the planned project? }\end{array}$ & YES \\
\hline 3 & $\begin{array}{l}\text { Does the report contain a description of the existing protected monuments located } \\
\text { in the immediate vicinity or in the immediate scope of the planned investment? }\end{array}$ & YES \\
\hline 4 & $\begin{array}{l}\text { Does the report contain a description of the envisaged environmental effects if the } \\
\text { project is not undertaken? }\end{array}$ & YES \\
\hline 5 & $\begin{array}{l}\text { Does the report contain a description of options (variants), taking into account the } \\
\text { specific characteristics of the project or its impact? }\end{array}$ & YES \\
\hline 6 & $\begin{array}{l}\text { Does the report contain a description of the expected impact of the analysed } \\
\text { options (variants) on the environment, including in the event of a serious industrial } \\
\text { accident, as well as a trans-border impact on the environment? }\end{array}$ & YES \\
\hline 7 & Does the report justify the variant proposed by the applicant? & YES \\
\hline 8 & $\begin{array}{l}\text { Does the report contain a description of forecasting methods applied by the } \\
\text { applicant and a description of the expected significant impacts of the planned } \\
\text { project on the environment? }\end{array}$ & YES \\
\hline
\end{tabular}


Table 2. cont.

\begin{tabular}{|c|l|c|}
\hline No. & \multicolumn{1}{|c|}{ Question } & $\begin{array}{c}\text { Answer } \\
\text { YES /NO }\end{array}$ \\
\hline 9 & $\begin{array}{l}\text { Does the report contain a description of the activities envisaged to limit, prevent or } \\
\text { compensate for the negative environmental impact on the environment? }\end{array}$ & YES \\
\hline 10 & $\begin{array}{l}\text { Does the report include assumptions for rescue research on monuments and } \\
\text { programs for securing existing heritage monuments against the negative impact of } \\
\text { the planned project, as well as provisions for landscape protection? }\end{array}$ & YES \\
\hline 11 & $\begin{array}{l}\text { Does the report contain a comparison of the installations used with the best } \\
\text { available technologies if necessary? }\end{array}$ & YES \\
\hline 12 & Does the report indicate the need to establish a limited use area? & YES \\
\hline 13 & Does the report present the issue in the illustrated (graphic) format? & YES \\
\hline 14 & Does the report present the issue in a cartographic format? & YES \\
\hline 15 & $\begin{array}{l}\text { Does the report include an analysis of possible social conflicts related to the } \\
\text { proposed project? }\end{array}$ & YES \\
\hline 16 & $\begin{array}{l}\text { Does the report contain proposals for monitoring the impact of the planned project } \\
\text { at the stage of its construction and operation or use, in particular on the forms of } \\
\text { nature protection? }\end{array}$ & YES \\
\hline 17 & $\begin{array}{l}\text { Does the report indicate difficulties resulting from technical deficiencies and gaps in } \\
\text { contemporary knowledge encountered during its development? }\end{array}$ & YES \\
\hline 18 & Does the report contain a Summary in a non-specialist language? & YES \\
\hline 19 & Does the report contain the signature of the author or team leader? & YES \\
\hline 20 & Does the report contain a statement from the author or team leader? \\
\hline 21 & $\begin{array}{l}\text { Does the report contain sources of information constituting the basis for preparing } \\
\text { the report? }\end{array}$ & YES \\
\hline
\end{tabular}

Source: elaborated by the authors based on [Report 2011] and [Act 2008].

From the formal point of view, the report on the impact on the environment of the project entitled "Construction of the eastern bypass road of Tuchów city along the provincial road No. 977" has been drawn up correctly. It meets all the requirements specified in article 66 of the UOOŚ [Act 2008]. The report has been prepared in detail and it contains all the elements referred to in Article 66 of the UOOŚ Act. Any deficiencies or missing elements were completed by the applicant and verified by the authority. All procedures were followed correctly during the proceedings, and the information required by law was made public. Also deadlines in which the public could comment on the planned investment have been adhered to. The decision on environmental conditions for the Tuchów bypass project issued by the Regional Director for Environmental Protection in Krakow was made available to the public. 


\section{Conclusions}

The conducted analysis showed that the planned Tuchów bypass road is consistent with the assumptions of the Local Spatial Development Plan for the Town and Municipality of Tuchów, and was included therein. All due procedures were followed during the proceedings. In addition, the report on the environmental impact of the undertaking meets all the requirements contained in article 66 of the UOOŚ and it can be considered correctly prepared. The investment project in question will not have a negative impact on the environmental elements presented in the report, and will not be a threat to human health. The low concentration of housing in its immediate vicinity favours this.

\section{References}

Act 2001. Ustawa z dnia 27 kwietnia 2001 r. o odpadach. Dz. U. z 2001 r. Nr 62, poz. 628.

Act 2008. Ustawa z dnia 3 października 2008 r. o udostępnianiu informacji o środowisku i jego ochronie, udziale społeczeństwa w ochronie środowiska oraz o ocenach oddziaływania na środowisko. Dz. U. z 2017 r., poz. 1227.

Bugajska A., Kulig A. 2014. Prawodawstwo w ochronie środowiska z elementami ocen oddziaływania na środowisko. Oficyna Wydawnicza Politechniki Warszawskiej, Warszawa.

Dubel K. 2005. Rola ocen oddziaływania na środowisko w systemie planowania przestrzennego. Oficyna Wydawnicza Politechniki Wrocławskiej, Wrocław.

Directive 2001. Dyrektywa Parlamentu Europejskiego i Rady 2001/42/EC z dnia 27 czerwca 2001 r. w sprawie oceny wpływu niektórych planów i programów na środowisko. Dz. U. L.197, 21.07.2001.

Directive 2002. Dyrektywa Parlamentu Europejskiego i Rady 2002/49/WE z dnia 25 czerwca 2002 r. w sprawie oceny i kontroli poziomu hałasu w środowisku. Dz.U. L.189, 18.7.2002.

Directive 2011. Dyrektywa Parlamentu Europejskiego i Rady 2011/92/EU z dnia 13 grudnia 2011 r. w sprawie oceny skutków wywieranych przez niektóre przedsięwzięcia publiczne i prywatne na środowisko naturalne. Dz.U. L.26, 28.1.2012.

Florkiewicz E., Kawicki A. 2009. Zeszyty Metodyczne Generalnej Dyrekcji Ochrony Środowiska. Postępowanie administracyjne w sprawach określonych ustawą z dnia 3 października 2008 r. o udostępnianiu informacji o środowisku i jego ochronie, udziale społeczeństwa w ochronie środowiska oraz o ocenach oddziaływania na środowisko. Ministerstwo Rozwoju Regionalnego, Warszawa.

Gawrońska G., Policht-Latawiec A. 2014. Ocena procedury wydawania decyzji o środowiskowych uwarunkowaniach z udziałem społeczeństwa. Acta Scientiarum Polonorum, ser. Formatio Circumiectus, 13(1), 31-44.

Kozioł J. 2008. Szlak „Wokół Tuchowa”. Przewodnik, Wydanie III. Wydawca Burmistrz Tuchowa, Tuchów.

Król M., Król K., Gawrońska G. 2017. Prognoza oddziaływania na środowisko miejscowego planu zagospodarowania przestrzennego - wybrane zagadnienia prawne. Acta Scientiarum Polonorum, ser. Administratio Locorum, 16(2), 87-96.

Regulation 2006. Rozporządzenie Ministra Środowiska z dnia 24 lipca 2006 r. w sprawie warunków, jakie należy spełnić przy wprowadzaniu ścieków do wód lub do ziemi oraz w sprawie substancji szczególnie szkodliwych dla środowiska wodnego. Dz. U. z 2006 r. Nr 137, poz. 984.

Regulation 2007. Rozporządzenie Ministra Środowiska z dnia 14 czerwca 2007 r. w sprawie dopuszczalnych poziomów hałasu w środowisku. Dz. U. z 2014 r., poz.112. 
Regulation 2010b. Rozporządzenie Rady Ministrów z dnia 9 listopada 2010 r. w sprawie przedsięwzięć mogących znacząco oddziaływać na środowisko. Dz. U. z 2010 r. Nr 213, poz. 1397 z późn. zm.

Report 2011. Raport o oddziaływaniu na środowisko dla przedsięwzięcia pn.: Budowa wschodniego obejścia Tuchowa w ciągu drogi wojewódzkiej nr 977, M. Wdowiak, M. Sułek, A. Korcz, A. Dębicki. 2011. Euromosty, Wrocław.

Resolution 2003. Uchwała nr XV/174/2003 Sejmiku Województwa Małopolskiego z dnia 22 grudnia 2003 r. w sprawie uchwalenia planu zagospodarowania przestrzennego województwa małopolskiego.

Resolution 2008. Uchwała nr XVII/144/2008 Rady Miejskiej w Tuchowie z dnia 27 lutego 2008 r. w sprawie uchwalenia miejscowego planu zagospodarowania przestrzennego gminy $\mathrm{Tu}-$ chów. Dz. Urz. Woj. Nr 300 z dnia 12 maja 2008 r., poz. 1999.

Dr inż. Grażyna Gawrońska

Uniwersytet Rolniczy w Krakowie

Katedra Melioracji i Kształtowania Środowiska

al. Mickiewicza 24/28, 30-059 Kraków

e-mail: grazyna.gawronska@urk.edu.pl

ORCID: https://orcid.org/0000-0001-8816-1367

Prof. dr hab. inż. Krzysztof Gawroński

Uniwersytet Rolniczy w Krakowie

Katedra Gospodarki Przestrzennej i Architektury Krajobrazu

ul. Balicka 253c, 30-198 Kraków

e-mail: krzysztof.gawronski@urk.edu.pl

ORICD: https://orcid.org/0000-0002-9922-7373

Dr inż. Karol Król

Uniwersytet Rolniczy w Krakowie

Katedra Gospodarki Przestrzennej i Architektury Krajobrazu

30-059 Kraków, al. Mickiewicza 24/28

e-mail:k.krol@onet.com.pl

website: http://homeproject.pl

ORICD: https://orcid.org/0000-0003-0534-8471

Hubert Buzowski

Uniwersytet Rolniczy w Krakowie

Katedra Melioracji i Kształtowania Środowiska

al. Mickiewicza 24/28, 30-059 Kraków 